\title{
China's new energy vehicles: value and innovation
}

Chris Kimble and Hua Wang

\begin{abstract}
Purpose

The overarching theme is the importance of innovations that are created within the emerging economies. More specifically, the article looks at the development of various alternatives to vehicles powered by the internal combustion engine, new energy vehicles (NEVs) within China.
\end{abstract}

\section{Design/methodology/approach}

The broad strategic approach of two sectors within the NEV sector in China, the pure electric vehicle (EV) and the low-speed electric vehicle (LSEV) sectors, are compared using recent data and conclusions are drawn.

\section{Findings}

The EV sector is viewed by the central government as a key sector for China's future industrial growth and is heavily supported. In contrast, the LSEV sector receives no support from central government and yet clearly outstrips the sales of EVs. The article argues that the latter's success is a reflection of the LSEV sector's focus on business model rather than technological innovation.

\section{Practical implications}

The article highlights the importance of monitoring innovations that come from within emerging economies and also illustrates the benefits that can come from commercially focused innovations rather than those based on technology.

\section{Social implications}

Finding alternatives to vehicles powered by fossil fuels is one of the most important challenges facing the world today. This article looks at the search for one alternative and examines its implications.

\section{What is original/of value?}

The article examines a business sector that is peculiarly Chinese and yet has potential implications far beyond China. It also contains recent sales figures and other data collected directly from sources in China.

\section{Introduction}

The automobile industry is of strategic importance to the world's economy. According to the International Organization of Motor Vehicle Manufacturers, the automobile industry has a global turnover of almost e2 trillion, which, if it were a country, would make it the world's sixth largest economy. In addition, they claim that the automobile industry accounts for over 5 per cent of the world's manufacturing jobs and that each directly created job supports at least another five jobs indirectly (OICA, 2012). However, it is also an industry facing a crisis. It is claimed that it has both an adverse effect on public health, through the various forms of pollution it causes, and contributes to global warming through carbon dioxide emissions from motor vehicles. Until recently, the economically advanced economies were seen as the prime culprits for these unwelcome side effects of the internal combustion engine (ICE); this now looks set to change as other parts of the world embark on industrial growth.

In the past two decades, the "emerging economies" (see Table I) have grown to become a significant economic force. The share of international trade accounted for by developing and emerging economies has risen from 30 per cent in 1995 to an estimated 45 per cent in 2010, with China and India acting as the two dominant poles for growth. While both Europe and 
America continue to suffer below average growth and high unemployment in the wake of the 2008 financial crisis, China and India now have growth rates of around 10 per cent (Dailami, 2011). This economic growth does not come without a cost since China is reported to emit more carbon dioxide than the US and Canada combined (Rogers and Evans, 2011) and has some of the most polluted cities in the world.

Table I A characterization of different types of economies

\begin{tabular}{|l|l|}
\hline \multicolumn{1}{|c|}{$\begin{array}{c}\text { Type of } \\
\text { Economy }\end{array}$} & \multicolumn{1}{c|}{ Characteristics } \\
\hline Advanced & $\begin{array}{l}\text { High-income economies that have traditionally been viewed as } \\
\text { technologically advanced, highly industrialized nations, e.g. European } \\
\text { Union, United States, or Japan. }\end{array}$ \\
\hline Emerging & $\begin{array}{l}\text { Economies with relatively high levels of industrialization, economic potential } \\
\text { and international engagement - typified by the BRIC nations (Brazil, Russia, } \\
\text { India and China). }\end{array}$ \\
\hline Developing & $\begin{array}{l}\text { Non-industrialized, low, and lower-middle-income countries whose } \\
\text { economies are usually based around the export of a limited number of } \\
\text { agricultural products. }\end{array}$ \\
\hline
\end{tabular}

What are the prospects for the future as the emerging economies continue to grow and the ownership of automobiles becomes more widespread? Where will the solution to the problems associated with ICE-powered vehicles be found? In this article, we examine the prospects of a solution coming from the emerging economies themselves. Specifically, we will look at the development of alternatives to ICE-powered vehicles in China. China has made new energy vehicles (NEVs) - a classification that covers both pure and hybrid electric vehicles - a key element of its industrial strategy. Below we examine the roles played by technological and business model innovation in one particular form of NEV, the electric vehicle (EV), and contrast the relative success of these two approaches. We begin this examination with a brief review of some of the current literature on technological and business model innovation in emerging economies.

\section{Technology innovation in emerging economies}

The resource-based view of the firm argues that resources that are rare, difficult to imitate and non-transferable lead to a long-term competitive advantage. For many years, firms in advanced economies have tended to equate these properties with technological superiority. However, as Mathews (2002) points out, most high-tech firms recognize that resources based on technological superiority alone eventually become transferable, and frequently use this fact to their advantage.

Much of the literature on technology and emerging economies focuses on the issue of technology transfer. The traditional argument is that technological innovations occur in the more advanced economies and, over time, diffuse into wider use. Authors such as Altenberg (Altenburg et al., 2012) argue that the capacity for technological innovation is only developing slowly in emerging economies. However, while it is true that most of the research behind new technologies takes place in the more advanced economies, the role of innovations elsewhere in the production chain should not be overlooked. The ways in which Chinese automobile manufacturers have transformed the product architecture of the motor car from a "closed integral" to "quasi-open" architecture, enabling them to produce a wide range of cars at a fraction of what it would cost an American or European manufacturer, is a perfect example of this (Wang and Kimble, 2010).

Bower and Christensen (1995), among others, have argued that apparently simple changes in process management can produce a "disruptive" technology that offers consumers a 
radically new value proposition; one that established firms are unable to understand or compete with. Later, Christensen claimed that these disruptive technologies often originated in "emerging markets remote from, and unimportant to, the mainstream" (Christensen, 1997, p. 15).

\section{Business model innovation in emerging economies}

According to Teece (2010, p. 172), a business model describes the way in which a firm "delivers value to customers, entices its customers to pay for value, and converts those payments to profit". A good business model means that a product offers value propositions that are compelling for customers, creates an advantageous infrastructure for the enterprise, and generates a substantial revenue stream. An inappropriate business model means that a product will either fail to deliver value or fail to capture it.

Using a similar argument to Bower and Christensen (1995), Mitchell and Coles (2003) contend that innovations in business models can also be "disruptive". However, the effect of business model innovation is less clear-cut. A new business model does not completely replace an existing business model in the way a new technology might but simply redefines how a product is seen and how it is offered to the customer. Thus, the advantage of business model innovation comes from the way it allows the same basic product to be offered in a new way, which yields more profit than can be obtained using the current business model.

There have been a few studies that look directly at business model innovation in developing or emerging economies. However, Hart and Christensen (2002, p. 52) draw attention to the potential value of such business models, observing that:

[...] business models that are forged in low-income markets travel well; that is, they can be profitably applied in more places than models defined in high income markets.

Similarly, David Chao, a partner with Doll Capital Management, explains that Chinese businesses have to "cater to extremely price-sensitive markets [...] that's why they have to come up with original solutions" (quoted in Mitra, 2009).

\section{Technology and business innovation in the new energy vehicle industry in China}

Having briefly reviewed what has been written about technological and business model innovation in emerging economies, we now examine two different sectors of the NEV industry in China. These represent two different solutions to China's problem of remaining a key player in the global automotive industry while simultaneously dealing with the environmental problems caused by the current generation of ICE-powered vehicles.

The first approach sees EVs as a straightforward substitute for ICE-powered vehicles. This approach enjoys the active support of the Chinese central government but needs to overcome a number of substantial technical problems in order to succeed. The second is a less high-tech version of an EV, the Low-Speed Electric Vehicle (LSEV) that uses a set of technologies already in existence. Although the development of the LSEV is not actively supported by the central government, it does have the support of some provincial governments and is already enjoying a surprising degree of commercial success. 


\subsection{The EV industry}

The development of EVs in China is driven mainly by the central government as part of a national strategy. The long-term ambition of the Chinese government is to replace ICEpowered vehicles with electrically powered alternatives that meet the same basic criteria with regard to cruising speed and cruising distance. This, however, creates a series of technical and logistical challenges which include the development of new product architectures (to accommodate the differing demands of EVs); new power systems (to replace the ICE by a battery); new drive trains (to replace the traditional drive train with an electrical version), and a new system for charging vehicles (using electrical power rather than hydrocarbon fuel). In brief, to reach the goal of creating a like-for-like replacement creates challenges throughout the entire value chain of the EV.

The initial development of EVs, which began with the eighth period of five-year planning (1991-1995), has now spanned two decades, with the central government dedicating significant resources to the task. In 2009, the State Council, the highest decision-making body in China, announced the target of reaching a production capacity of 500,000 units for NEVs, representing 5 per cent of the total annual market for passenger car sales.

Table II Sales of pure electric vehicles within China, 2011

\begin{tabular}{|l|l|l|}
\hline Carmaker & Sales Volume & Market share \\
\hline Chery & 1,400 & $25 \%$ \\
\hline JAC & 1,252 & $22 \%$ \\
\hline BYD & 435 & $8 \%$ \\
\hline Zotye & 300 & $5 \%$ \\
\hline Haima & 220 & $4 \%$ \\
\hline Others & 1,972 & $35 \%$ \\
\hline All China & 5,579 & $100 \%$ \\
\hline \multicolumn{3}{|c|}{ Source: Jiang (2012) }
\end{tabular}

But the sales figures for EVs have been disappointing, with only 5,579 pure electric vehicles sold in 2011 (Table II). The gap between these ambitious plans and the commercial reality has forced the government to revise its original strategy, with several changes to objectives, policies and the definition of NEVs being made since 2009 (Table III).

Table III China new energy vehicle policy adjustments between 2009 and 2012

\begin{tabular}{|l|l|l|l|l|}
\hline & $\begin{array}{c}\text { Decision } \\
\text { Making Body }\end{array}$ & \multicolumn{1}{|c|}{ Objective } & \multicolumn{1}{|c|}{$\begin{array}{l}\text { Policy or } \\
\text { regulation }\end{array}$} & $\begin{array}{l}\text { Definition of } \\
\text { New Energy } \\
\text { Vehicle }\end{array}$ \\
\hline 2009 & State Council & $\begin{array}{l}\text { By 2012, NEVs to } \\
\text { represent 5\% of total } \\
\text { passenger cars sales. The } \\
\text { annual production capacity } \\
\text { of NEVs to reach 500,000 } \\
\text { units. }\end{array}$ & $\begin{array}{l}\text { Regulation on the } \\
\text { Plan for } \\
\text { Revitalization of } \\
\text { Automobile Industry }\end{array}$ & $\begin{array}{l}\text { Pure EV, } \\
\text { PHEV and fuel } \\
\text { cell vehicles }\end{array}$ \\
\hline 2012 & $\begin{array}{l}\text { Ministry of } \\
\text { Industry and } \\
\text { Information } \\
\text { Technology }\end{array}$ & $\begin{array}{l}\text { By 2015, the cumulative } \\
\text { sales of NEVs to reach } \\
500,000 \text { units and by } \\
\text { 2020, mastery of EV } \\
\text { technology. }\end{array}$ & $\begin{array}{l}\text { Twelfth five-year } \\
\text { plan on New } \\
\text { Material Industry } \\
\text { Development }\end{array}$ & $\begin{array}{l}\text { Pure EV, } \\
\text { PHEV, fuel cell } \\
\text { vehicle and } \\
\text { PEMHVs }\end{array}$ \\
\hline
\end{tabular}

Source: Web site of Ministry of Industry and Information Technology, www.miit.gov.cn

The combined effect of these changes has been to lower the technology barrier by, for example, including petro-electric micro hybrid vehicles (PEMHVs), an ICE based start-stop hybrid micro car, within the definition of a NEV. In addition, there has also been a scaling 
down of the highly optimistic initial target, from an annual production capacity of 500,000 units by 2012, to a cumulative sales figure of 500,000 units by 2015 .

\subsection{The LSEV industry}

In parallel to the government-sponsored development of the EV, there has also been the development of a different type of NEV, the LSEV. LSEVs first appeared in China as electrically powered farm vehicles. Early LSEVs were designed to carry people and loads for short distances along farm tracks; later versions were based on popular models of small cars, such as the QQ from Chery. A typical LSEV consists of a simple electric motor powered by a lead acid battery pack. The motor is connected directly to the accelerator and the typical top speed is between 40 and $60 \mathrm{~km} / \mathrm{h}$.

The initial market for LSEVs was mainly rural areas where household incomes were low; typically less than a third of those of urban consumers. The purchase price of a LSEV is around half that of an ICE powered vehicle and the cost per $\mathrm{km}$ of electricity is around eight times less than the equivalent cost of petrol. In addition, the simple product architecture of a LSEV reduces maintenance costs and makes it easier for the non-specialist to repair. Finally, networks of gas-stations are poorly developed in rural areas and, as the lead-acid battery can be charged from an ordinary 220 -volt outlet, using LSEVs eliminates the need to drive to the nearest gas station to refuel.

Aided in part by design changes to the appearance of the vehicle, the market for LSEVs has now begun to grow in urban areas. The top speed of a LSEV corresponds to the standard downtown speed limit of $60 \mathrm{~km} / \mathrm{h}$ and most urban commuting distances are less than $20 \mathrm{~km}$; consequently, a LSEV can meet the daily transportation needs of most urban consumers. However, unlike the pure EV, the LSEV does not enjoy the support of central government. LSEVs are not classified as NEVs and, according to existing law, do not have the right to use public highways in China.

But a few provincial governments have lobbied for the wider acceptance of LSEVs and have created "temporary" local policies to encourage the use of LSEVs. For example, Shandong province, a largely agricultural economy with a population of around 100 million, allows LSEVs to use its roads and has offered road tax and road charge waivers for their owners. It has also created the "New Energy Vehicle Technology Innovation Alliance", which published the first set of standards for the testing, safety and environmental impact of LSEVs.

Despite ambiguity about their legal status and the lack of support from the central government, LSEVs have been a commercial success in China. Sales in Shandong Province alone (Table IV) are more than 13 times the total sales of pure EVs for the whole of China.

Table IV Sales of LSEVs in China (2011)

\begin{tabular}{|l|l|l|l|}
\hline Province & Sales Volume & Key Producers of LSEVs & \multicolumn{1}{c|}{ Industrial Base } \\
\hline Shandong & 77,209 & Shifeng, Byvin & Low Speed Vehicles \\
\hline Hebei & 20,000 & Xin Yuzhou, Yujie & Motorcycle, Auto Components \\
\hline Jiangsu & 10,000 & Sunra, Yedea & Electric Bicycle \\
\hline Zhejiang & 10,000 & Kandi & Electric Bicycle, Auto Components \\
\hline All China & 120,000 & \multicolumn{2}{|c}{}
\end{tabular}

Source: Authors' estimates based on data from a variety of sources

\section{A comparison of the success of the EV and LSEV in China}

How is it that the sales of an unglamorous low-tech, low-speed vehicle in one province can outstrip the sales for the whole of China of a high-tech vehicle that is seen as being one of 
the pillars of China's future industrial development? The key points concerning differences of approach in the two industries are summarized in Table $V$ and discussed in greater detail below.

\subsection{The approach of the EV industry}

As noted earlier, attempting to create a substitute for the current range of ICE powered vehicles is a major technological challenge. The Chinese automobile industry has attempted to improve current technologies across the entire array of components used in EVs in much the same way as the Japanese consumer electronics industry set about modifying the whole range of components used in their products (Kimble and Wang, 2012). For EVs, this includes major components, such as the battery and the motor, smaller components such as battery management systems and drive trains, as well as externalities such as charging stations.

Altenburg et al. (2012) comment on the interrelated nature of the problems that need to be solved. For example, the weight of the batteries is not only a problem for speed and cruising distance, but it also creates a new set of demands for the body shell that will carry them. Similarly, removing the engine block and drive train frees space, but also creates other problems for the architecture of the vehicle (e.g. the behaviour of the vehicle in an accident). Even without considering the associated problems of charging stations, it is clear that attempting to build an EV that can act as a direct replacement for the current generation of ICE powered vehicles creates an assortment of technological problems that are ever more complex, expensive and difficult to solve.

\subsection{The approach of the LSEV industry}

In contrast to EVs, LSEVs already enjoy a modest degree of commercial success in China. They offer a different solution to the problems outlined earlier; one based on business model rather than technological innovation. It has been argued elsewhere (Kimble and Wang, 2012) that the LSEV has the potential to be disruptive in the sense that Mitchell and Coles (2003) use the term. However, to do so the concept of low-speed, short distance transport will need to become more widely accepted. The challenge here lies in creating the right business model to make this happen rather than improving the performance of the technology.

The LSEV offers an attractive value proposition to Chinese consumers; particularly those in rural areas, but also to those who live in cities. However, conditions faced by consumers in the more technologically advanced economies are not that different; most people live in urban areas with speed limits of $60 \mathrm{~km} / \mathrm{h}$ or less and travel under $50 \mathrm{~km} / \mathrm{day}$. Hart and Christensen (2002) noted that business models forged in low-income markets tend to travel well - can a business model for the LSEV be constructed and made to travel more widely?

For the LSEV to be accepted in advanced economies it would require more radical change than in China where there is no established "automobile culture" and consequently the introduction of an "alternative" means of transport such as a LSEV has proved easier. For nations in which car ownership is already widespread, it would call into question current perceptions about the social utility of car ownership and would mean a change in the assumptions that underpin most urban planning. Even with a new generation of more environmentally conscious consumers, the future of such a radical alternative outside China still is uncertain. 
Table V Comparison between EV and LSEV in China

\begin{tabular}{|c|c|c|}
\hline & EV & LSEV \\
\hline Strategic objective & $\begin{array}{l}\text { Create substitute for the ICE } \\
\text { powered passenger car }\end{array}$ & $\begin{array}{l}\text { Create an alternative to the ICE } \\
\text { powered passenger car }\end{array}$ \\
\hline Core logic & $\begin{array}{l}\text { Long distance, high speed, } \\
\text { luxury cruising vehicle which can } \\
\text { be used for many things }\end{array}$ & $\begin{array}{l}\text { Short distance, low speed, } \\
\text { alternative which is } \\
\text { complementary to ICE vehicles }\end{array}$ \\
\hline \multirow[t]{2}{*}{ Product architecture } & $\begin{array}{l}\text { Mostly based on existing ICE } \\
\text { vehicle architecture }\end{array}$ & $\begin{array}{l}\text { Mostly based on golf-cart or } \\
\text { mini-car architecture }\end{array}$ \\
\hline & Integrated / Closed & Modular / Quasi Open \\
\hline \multirow{3}{*}{ Strengths } & $\begin{array}{l}\text { Strong support from central and } \\
\text { most regional governments }\end{array}$ & $\begin{array}{l}\text { Strong support from certain } \\
\text { regional governments }\end{array}$ \\
\hline & Capital and institutional support & $\begin{array}{l}\text { Attractive product for low-income } \\
\text { consumers in China }\end{array}$ \\
\hline & $\begin{array}{l}\text { Based on existing ICE vehicle } \\
\text { industry infrastructure and } \\
\text { technology }\end{array}$ & $\begin{array}{l}\text { Based on existing e-motorcycle / } \\
\text { golf-cart industry infrastructure } \\
\text { and technology }\end{array}$ \\
\hline \multirow{4}{*}{ Challenges } & Low volume of sales & Legal status of vehicles \\
\hline & $\begin{array}{l}\text { Complexity of technology } \\
\text { throughout the value chain }\end{array}$ & $\begin{array}{l}\text { No industrial policy support from } \\
\text { central government }\end{array}$ \\
\hline & $\begin{array}{l}\text { Complex externalities such as } \\
\text { charging stations }\end{array}$ & $\begin{array}{l}\text { Dealing with environmental and } \\
\text { safety issues }\end{array}$ \\
\hline & $\begin{array}{l}\text { Uncertainty on the development } \\
\text { of future technology standards }\end{array}$ & $\begin{array}{l}\text { Lack of any widely accepted } \\
\text { technology or safety standards }\end{array}$ \\
\hline Focus of innovation & $\begin{array}{l}\text { Improve technology throughout } \\
\text { the value chain to overcome } \\
\text { technological problems of EV }\end{array}$ & $\begin{array}{l}\text { Create a customer oriented } \\
\text { business model based on } \\
\text { convenience and low price }\end{array}$ \\
\hline
\end{tabular}

\section{Some comments on innovations from emerging economies}

The case study of the EV and LSEV in China is an opportunity to look at the nature and potential impact of an innovation that originates from within an emerging economy. In this final section, we comment on the lessons that may be drawn from this.

First, our work highlights the need to take a more decentralized view of innovation and to monitor innovations that come from the emerging economies. The past experience of "disruptive" innovations from Japan and Korea has already demonstrated the risks of not doing so. As we noted in the introduction, the number of competitors from emerging economies will almost certainly increase and their "non-orthodox" approach to innovation, such as quasi-open product architecture in automobiles could have profound implications for existing companies.

Second, we make the point that commercially focused innovations can have a greater impact than those based on technology. This is particularly the case in emerging economies where markets are growing quickly while basic science lags behind. As Leibowitz and Roth (2012) observed in their interview with Kevin Wale, the managing director of GM in China:

What China does better than any place else in the world is to innovate by commercialization, as opposed to constant research and perfecting the theory, like the West. When the Chinese get an idea, they test it in the marketplace [...] That's an innovative way of doing innovation, something that the rest of the world is struggling to understand.

Finally, we highlight the fact that for innovations to succeed, we have to "think out of the box" - both technically and commercially. The inertia that comes from dependence on existing

C. Kimble and $\mathrm{H}$. Wang. China's new energy vehicles: value and innovation. Journal of Business Strategy, 34(2), 2013, pp. 13 - 20. DOI: 10.1108/02756661311310413 
designs and an unquestioned acceptance of the accepted wisdom can blind firms to the potential of new ideas. Again, as Kevin Wale observed when talking about General Motor's approach to the development of electric vehicles in China:

We will have an advanced design center here for the same reason. It's hard to imagine doing advanced design without taking into account the influence of the largest and fastest-growing market in the world. So we're putting in a starting point where we will have the basis for future creativity in the country.

In the end, the LSEV may not provide the answer to the needs of future generations for personal mobility. However, we show in this article that a vehicle starting life as farm vehicle and still not officially allowed on the roads can easily outstrip the sales of an alternative supported by the central government of the most populous state in the world and the second richest nation after the USA. Perhaps that alone should give us pause for thought.

\section{References}

Altenburg, T., Bhasin, S. and Fischer, D. (2012), "Sustainability-oriented innovation in the automobile industry: advancing electromobility in China, France, Germany and India", Innovation and Development, Vol. 2 No. 1, pp. 67-85.

Bower, J.L. and Christensen, C.M. (1995), "Disruptive technologies: catching the wave", Harvard Business Review, Vol. 73 No. 1, pp. 43-53.

Christensen, C.M. (1997), The Innovator's Dilemma: When New Technologies Cause Great Firms to Fail, Harvard Business Press, Boston, MA.

Dailami, M. (Ed.) (2011), Multipolarity: The New Global Economy, The International Bank for Reconstruction and Development, Washington, DC.

Hart, S. and Christensen, C.M. (2002), "The great leap: driving innovation from the base of the pyramid", MIT Sloan Management Review, Vol. 44 No. 1, pp. 51-5.

Jiang, C.X. (2012), "Production and sales report on China new energy vehicle", EVTimes, January, available at: www.evtimes.cn/html/news/q/z/2012/0208/35342_2.html (accessed 9 April 2012).

Kimble, C. and Wang, H. (2012), "Transistors, electric vehicles and leapfrogging in China and Japan", Journal of Business Strategy, Vol. 33 No. 3, pp. 22-9.

Leibowitz, G. and Roth, E. (2012), "Automotive innovation in China: the view from General Motors", McKinsey Quarterly, February, available at: www.mckinseyquarterly.com/Strategy/Innovation/Three snapshots_of_Chinese_innovation_2918 (accessed 11 Appril 2012).

Mathews, J.A. (2002), "Competitive advantages of the latecomer firm: a resource-based account of industrial catch-up strategies", Asia Pacific Journal of Management, Vol. 19 No. 4, pp. 467-88.

Mitchell, D.W. and Coles, C.B. (2003), "The ultimate competitive advantage of continuing business model innovation", Journal of Business Strategy, Vol. 24 No. 5, pp. 15-21.

Mitra, S. (2009), "China's innovation advantage", available at: www.forbes.com/2009/08/06/china- innovation-dcm-intelligent-technology-david-chao.html (accessed 12 August 2009).

OICA (2012), "International Organization of Motor Vehicle Manufacturers", available at: http://oica.net/ (accessed 1 August 2012). 
Rogers, S. and Evans, L. (2011), "World carbon dioxide emissions data by country", available at: www.guardian.co.uk/news/datablog/2011/jan/31/world-carbon-dioxideemissions-country-data-co2 (accessed 16 May 2012).

Teece, D.J. (2010), "Business models, business strategy and innovation", Long Range Planning, Vol. 43 Nos 2-3, pp. 172-94.

Wang, H., \& Kimble, C. (2010). Low-cost strategy through product architecture: lessons from China. Journal of Business Strategy, 31(3), 12-20. 